\title{
The Diversity and Causality of Pension Reform Pathways: A Fuzzy-set Qualitative
}

\section{Comparative Analysis}

Leandro N. Carrera and Marina Angelaki

Accepted article. First published online in Journal of Social Policy 4 November 2019

Pension reform is one of the top public policy priorities in advanced industrialized countries due to population ageing and the significant weight of pension spending in governments' budgets. As a result of these concerns European countries have engaged in varying degrees of pension reforms over the last three decades. The extant literature on pension reform focuses on structural, institutional and blame avoidance theories to explain how pension reform take place. Yet, how do different conditions combine to lead to significant pension reform outcomes? To answer this question we analyze a set of 48 pension reform cases in eight European countries since the late 1980s up until 2014 by using fuzzy set qualitative comparative analysis ( $\left.f_{s} Q C A\right)$. Our main finding is that institutional, structural or blame avoidance theories cannot account by themselves for instances of significant pension reform Rather, we find three pathways that combine structural and institutional conditions to lead to significant pension reform.

\section{Introduction}

Pension reforms implemented since the early 1990s have been far from uniform in terms of their content and direction and have attracted scholarly attention on the ways in which different socio-economic, institutional and other factors affect reform processes and outcomes. While Bismarckian pension systems have been described as "frozen landscapes" (Esping-Andersen 1990), a term used to denote their inertia, studies have shown "elephants to be on the move" (Hinrichs 2000). In Italy, for example, socio-economic conditions, the EMU process through its impact on debt and deficit levels, concertation with the social partners and changes in the political landscape have combined during the 1990s to open a window of 
opportunity, absent until that point, that allowed the introduction of path-departing pension reform through the adoption of a notional defined contribution system ${ }^{1}$ (Natali 2004). By contrast, Greece has been unable to introduce significant pension reforms as institutional legacies have proven far stronger than the EU pressure for change, leading to path-dependent reforms (Sotiropoulos 2004).

In the case of pension systems in central and eastern European countries Müller (1999) has shown how reform outcomes have varied as a result of the differences in the structural setting and the constellations and interactions of relevant political actors. For example, in Hungary, the economic pressures (rise in unemployment and inflation) that arose during the transition from state socialism to market economy combined with institutional factors allowed the carving-out of a second mandatory pension pillar between 1998 and 2004 (Müller 1999). Following the 2008 crisis, the need to reduce pressure on finances and the European Commission's negative response to the Hungarian and other European countries' request to exclude transition costs of pension privatization from debt and deficit accounts, along with favorable institutional factors, led to the elimination of the second pillar (Simonovits 2011). Other EU countries subject to adjustment programmes, such as Portugal, Greece, Cyprus, and Ireland, have witnessed during the crisis the increase of EU intrusiveness in welfare state reform (Theodoropoulou 2014).

Motivated by the fact that significant pension reforms are potentially complex and result from the combination of different causes, we explore the conditions that must be present for

\footnotetext{
${ }^{1}$ Notional defined contribution (NDC) systems mimic a funded system of individual accounts, yet with a PAYG financing structure (where workers pay contributions that are used to finance current pensioners). In NDC systems contributions are tracked in accounts which earn a rate of return which is set by the government and is not the product of investment return as accounts are notional. Upon reaching pension age, accumulated contributions and notional returns are converted into an annuity.
} 
significant pension reforms to occur. Our specific focus is on the impact of reforms on the architecture of the retirement system as a whole (Hinrichs and Kangas 2003). Thus, "significant pension reform" (SPR) is defined in this paper as a reform entailing the introduction or elimination of a mandatory second pillar of private pension accounts that results in what Hall (1993) terms "paradigmatic change". Using fuzzy-set Qualitative Comparative Analysis (fsQCA) we show that significant pension reform is the result of three different pathways that combine significant unemployment with either the absence of legislative fragmentation, significant government deficit levels or a strong labor movement.

Through the analysis of pension reforms using fsQCA, we aim to contribute to the literature on the methods and approaches that can be used for the study of welfare state and pension politics while also acknowledging some of its limitations. Furthermore, we aim to show how our findings may challenge or, at least complement, some of the assumptions of wellestablished theories.

\section{The Politics of Pension Reform}

Welfare state (and pension) reforms since the mid 1980s have sparked the attention of scholars and have led to a vast literature seeking to explain the mechanisms and content of such reforms. In terms of reform content, while initial attention focused on retrenchment (Pierson 1994, 1996) a more refined approach highlighted three dimensions of welfare restructuring: cost-containment, recalibration and recommodification (Pierson 2001). While cost-containment is associated with cutbacks, recalibration entails updating "to adapt to changing norms and demands" and/or rationalization ("modification of programmes in line with new ideas about achieving established goals"). By contrast, recommodification focuses on enhancing active labor force participation. According to Pierson (2001) each welfare 
regime follows a different route in the face of intense pressures for austerity. The liberal focuses on cost-containment and recommodification, the social democratic on costcontainment and recalibration (rationalization) and the conservative on cost-containment and recalibration (updating of old programmes).

Social policy scholars have also used Hall's framework to assess the degree of innovation introduced in specific reforms and thus the extent at which reforms affect the instruments and/or the overall logic of the system. The proposed framework distinguishes between three types of changes (Hall 1993). The first type involves changes in the setting of instruments (such as an increase in social contributions or a decrease of benefit levels). The second type entails the introduction of new instruments, such as new rules for the calculation of benefits, while the third type (paradigmatic changes) involves the introduction of new goals. As pointed out by several scholars (Bonoli and Palier 2007, Hinrichs and Kangas 2003) pathdependent changes (such as second types ones) may nonetheless lead to a paradigm shift as their effects take years to materialize.

Turning to the factors driving pension reforms, the neo-functionalist approach highlights socio-economic factors like deepening economic integration, demographic pressures, and unemployment. Yet, while all Western European countries are faced with significant demographic changes, these have not translated in similar reform outcomes (cf. cases of Italy and Greece cited in the introduction). The pressure on the financing of public pension systems as a result of the industrial reconversion and the rise of unemployment has led Huber and Stephens (2001) to argue that unemployment is a stronger explanatory factor of welfare and pension reform compared to demographic change. But as their impact on the timing and extent of reforms is still debated, socio-economic changes are seen more as the triggers of 
reform processes in turn mediated by political-institutional factors (Rodrik, 1996; Starke, 2006). In his seminal work, Paul Pierson $(1998,2001)$ showed how changes in the global economy, population ageing and the expansion of welfare states (what he terms "irresistible forces") meet with the "immovable objects" (the popular support of programmes and institutional stickiness related to veto points within formal institutions and path-dependent processes) to put severe obstacles to the dismantling of the welfare state. Pierson showed that reform is possible in such context through a strategy based on compromise and leading to the restructuring (rather than dismantling) and modernization of the welfare state. To avoid blame for unpopular policies, policymakers may resort to compensation and obfuscation strategies. For example, Bonoli and Palier (2007) highlighted the importance of sequencing such as the introduction of long-phasing in periods and the gradual shift towards funding.

Focusing on the role of institutions Bonoli (2000) explains that institutional settings that provide power concentration to the executive and fewer veto points for opponents facilitate reforms. However, he points out that the impact of political institutions is mediated by electoral results and the mobilization of strong societal groups like labor unions. Readapting the institutional approach, Immergut et al. (2007) explain the adoption of pension reforms despite the existence of a significant number of veto players by reference to political competition. When the latter is intense (because for example the electoral system provides ways for voters potentially affected by the reform to vote against the government), policy makers will either seek consensus for the proposed measures or withdraw them.

For scholars studying the role of institutions, the structure of the pension system is an equally important aspect in shaping reform outcomes. The crowding-in thesis postulates that mature Bismarckian pension systems leave little room for the development of private occupational 
pensions as they provide sufficient earnings-related benefits. At the same time, social partners are already involved in pension systems' administration and as such not interested in setting additional pension schemes. By contrast, Beveridge basic pension type systems are expected to provide more room for the introduction of occupational pensions (Hinrichs 2000, Myles and Pierson 2001). As more recent analyses have shown, reform of public pension systems has been facilitated by the introduction of occupational pensions in Bismarckian systems (Ebbinghaus 2011). In the case of mature multi-pillar systems as those of the UK and the Netherlands, changes have been described as "path-dependent incremental adaptations to the changing socio-economic environment" (Ebbinghaus 2011).

The power resources theory has in turn placed focus on the role of class struggle and political mobilization, usually led by strong labor unions, in the expansion of the welfare state, (O'Connor and Olsen 1998). As rightly pointed out though, the emergence and maturation of welfare states has created at the same time groups benefiting from them such as pensioners, in addition to those associated with its expansion like political parties and workers' movements. As Pierson (1996) puts it "maturing social programs develop new bases of organized support that have substantial autonomy from the labor movement". While Pierson highlights the emergence of new beneficiaries, like the American Association of Retired Persons, to support the decline of the role of trade unions, this does not seem to be the case in Continental Europe. On the contrary, trade unions in European countries have played an important role in negotiated reforms (social pacts) in advancing unpopular reforms through a trade-off strategy (Ebbingaus 2011, Natali and Rhodes 2007). Gelepithis (2018) study on the ways of achieving more encompassing private pensions argued that unions' demands can come about through different pathways: collective self-regulation and top-down regulation in Continental Europe; top-down regulation in Anglophone countries. Korpi and Palme (2003) 
have shown that partisan politics still matters in understanding welfare reform in the context of austerity. In this context, Green Pedersen (2003) showed in his study on welfare reforms in Denmark and the Netherlands how party politics affected the establishment of broad political agreement on socioeconomic policy that also encompassed welfare state reforms.

Abou-Chadi and Immergut (2018) examine electoral competition stressing that welfare state politics now involve trade-offs between "new" versus "old" social rights (or social investment versus social consumption). Studying 10 OECD countries between 1980 to 2011 the authors find that when electoral competition intensifies left governments are willing to prioritize social investment to the expense of pension right generosity to be able to expand programmes for new social risks. Meanwhile centre-right governments avoid retrenchment on pension rights and pension expenditure. The emphasis on electoral competition allows the authors to show how parties can depart from their traditional policy positions depending on the degree of competition.

The recent crisis has also revived the interest on the role of international organizations in the pension reform process. Orenstein $(2005,2011)$ showed the role of international organizations (primarily the World Bank's) in the diffusion of pension privatization ideas worldwide starting in the 1990s. Other scholars (Beland 2009, Schmidt 2003, Schmidt and Radaelli 2004) stressed the role of ideas in the construction of the issues and problems that enter the policy agenda, by shaping the economic and social assumptions that legitimize or challenge existing institutions and policies. Yet the influence of ideas is at most indirect in shaping national reform processes. Following the 2008 crisis, EU countries that required financial assistance, have witnessed an increase of international actors' intrusiveness. Yet, related studies have shown that the degree of intrusiveness has been far from uniform (Hick 
2017, Theodoropoulou 2014). For the rest of the EU countries the need to abide to the new economic governance framework puts further pressure on member states and prohibits reforms with a negative impact on debt and deficit levels.

To sum up, there seem to be three broad hypotheses on pension reform coming out from theoretical approaches that have focused on structural factors, class struggles and institutions:

H1: Following the analyses on structural and socio-economic conditions, significant pension reforms are expected in situations in which a country faces negative socio-economic conditions such as high unemployment and weak government finances.

H2: The expectation of the institutional analyses is that a strong government and a weak labor movement should make significant pension reforms more likely. This also aligns with the expectation of the power resource theory.

H3: By contrast, the literature on the "new politics of the welfare state" expects significant pension reforms to be easier in settings where there is a weak government and a weak labor movement as it could be easier to "hide" and "distribute" the blame for costcutting significant pension reform.

The above review on welfare and pension reform suggests that pension reform processes are complex phenomena affected by the interaction of socio-economic, institutional, and political mobilization conditions. Significant pension reform is expected to be met in different ways as a result of the different socio-economic and institutional context in which they take place and in which party politics may differ. So far, comparative studies have been good in describing how different conditions may combine to explain significant reform. Nonetheless these analyses tend to be highly descriptive and focused on few cases. Against this background, we 
aim to account for the possible multiple causes that may combine in different ways to explain pension reform in a more systematic way.

\section{Research Design, Method and Data}

As pension reforms are complex phenomena and as such are expected to be met in different ways, we analyze them using Fuzzy Set Qualitative Comparative Analysis. Fuzzy set Qualitative Comparative Analysis (fsQCA) has been proposed by many scholars in public policy analysis as an alternative to case-oriented and quantitative regression-based approaches, as it can handle research designs with a relatively small number of observations while still providing parsimonious results and acknowledging the complexity of each case (Rihoux and Ragin 2009). Critically for our research, fsQCA assumes cases as combinations of different values for the outcome of interest and the causal conditions. fsQCA can also account for causal complexity, which is given by the fact that a combination of different causes may lead to an outcome of interest (Ragin, 2000, Ragin, 2008, Rihoux \& Ragin, 2009). Furthermore, fsQCA can account for equifinality, i.e. a situation in which an outcome may follow from different combinations of causal conditions, that is, from different causal "recipes" (Ragin 2008, p.23). Causal complexity and equifinality are important aspects to be considered when comparing cases of pension reforms as it has been shown that they are likely to be the result of complex combinations of conditions (Gelepithis 2018). Yet, as pointed out by Rihoux and Ragin (2008), fsQCA does not make a statement on the causal process but rather on the causes or combination of them that must be present for an outcome to occur. It is then up to the investigator to use substantive knowledge on each case to identify the causal mechanism at play.

In contrast to quantitative regression-based techniques, fsQCA is grounded in set theory. Cases are understood as combinations of different set theoretic values for the outcome of 
interest and for the causal conditions. The outcome to be explained and the different causal conditions are assumed to range from no membership to full membership in a given set condition. Full membership is denoted by a value of 1 and no membership with a value of 0 . Partial membership in a set condition are given values between 1 and 0 . Membership scores greater than 0.5 indicate that a case is "more in than out" in the set condition, scores close to 1 indicate that a case is "mostly in" a set condition, scores close to 0 indicate that a case is "mostly out", and so on. Full membership (1) and full non-membership (0) are understood as qualitative states, not arbitrary values (i.e., the highest and lowest observed scores). Thus, the calibration of membership in a fuzzy set involves both quantitative and qualitative assessments and must be grounded in theoretical and substantive knowledge of the cases being analyzed (Ragin 2008).

Once the researcher has coded all the cases as combination of values for the outcome and the causal conditions, they can be analyzed using the fsQCA software. fsQCA identifies necessary and sufficient conditions by using the concepts of sets and subsets. A necessary condition represents a condition that, if the outcome of interest is present, the condition must also be present. Thus, if a condition is necessary, it implies that it contains the outcome of interest (the outcome is a subset of the cause). If a condition (or combination of conditions) is sufficient, it means that the condition must be present for the outcome to take place. In this case, the outcome contains the cause (the cause is a subset of the outcome). fsQCA accounts for the complexity of social phenomena by identifying the different necessary conditions and the combination of different causes that may be sufficient to observe an outcome of interest (Ragin 2008).

Cases, outcome and calibration 
We look at 48 instances of pension reform in eight European countries (Greece, Germany, Hungary, Italy, the Netherlands, Switzerland, Sweden and the United Kingdom) between 1986 and 2014. From a comparative point of view the countries under study are all broadly similar in that they are all advanced industrialized and in Europe. At the same time, they belong to different "worlds of welfare capitalism" (Esping-Andersen 1990). More importantly, the eight countries have implemented reforms over this period that have ranged from parametric ones, where parameters of the system are changed such as the benefit indexation mechanism or the retirement age, to paradigmatic ones entailing the introduction or elimination of a mandatory second pillar of private accounts, resulting in a change of the system architecture (Immergut et al 2007). Thus, understanding the causal complexity behind instances of pension reform can yield interesting insights to understand pension reforms in other industrialized countries.

Each case is composed of a specific fuzzy set value for the outcome and the causal conditions outlined further below, which are based on the theoretical expectations analyzed in the previous section. The total number of cases is 48 , which provides a good degree of analytical leverage given the variation in the casual conditions.

The outcome of interest is defined as significant pension reform (SPR). The extant literature on pension reform has distinguished between parametric and paradigmatic / structural reforms (Bonoli and Palier 2008, Hll 1993, Hinrichs and Kanfas 2003, Myles and Pierson 2001; Brooks 2009; Immergut et al 2007). Parametric reforms typically include changes such as the retirement age or the benefit indexation formula. By contrast structural reforms may include a change in the architecture of the system through the introduction of new goals such as in our case the introduction or removal of an existing pillar. 
We build on this categorization to define and calibrate SPR. Namely, we define significant pension reform (SPR) as one that changes the architecture of the current system (Hinrichs and Kangas 2003) so that the components of retirement income are altered altogether, via the introduction or elimination of a mandatory private pillar. Thus, the cut-off for determining full membership in the set of significant pension reform is given by whether a reform entails the introduction or the elimination of a mandatory private pillar. These cases are given a fuzzy set value of 1 . The cut-off for non-membership in this set is given by whether a reform entails only administrative changes or benefit indexation changes. These cases are given a fuzzy set value of 0 .

To further construct the remaining fuzzy set values for SPR we consider key policy components of pension reforms that may be subject to change. These include changes to: retirement age, minimum contribution levels and the funding principle. Table A1 in the annex summarizes the full fuzzy set calibration for the outcome. As can be seen, we do not include a 0.5 membership, which would be neither in nor outside of the set of significant pension reform. This is because, as indicated by the literature, we believe that pension reforms will always either tend to be of a structural or parametric nature. In fuzzy set terms, reforms with a structural tendency will be "mostly in the set" (0.75) or "in the set" (1) of significant pension reform. These cases will include instances of reforms that introduce or eliminate a mandatory pillar (which receive a fuzzy set value of 1) or instances of reforms that change the funding principle of the first public pillar (as in Italy in 1995) or aim to increase participation in a non-mandatory private pillar, for example via automatic enrolment as in the UK since 2008 (which receive a fuzzy set value of 0.75 ). The underlying logic to calibrating these reforms as "mostly significant" is that the composition of income in retirement is likely 
to be altered to a large extent, even if a new mandatory pillar is not introduced or eliminated. For example, in Italy future pensioners will have their pension benefit from the public pillar calculated in a new way that is likely to result in less adequate pensions than under previous rules (Natali and Rhodes 2007). In the UK the proportion of retirement income from private pensions for future pensioners will increase to a large extent as a result of automatic enrolment and low opt-out rates (PPI 2014). Parametric reforms will be mostly out (0.25) or definitely out of the set of significant reform (0). These will include cases of reforms that increase the retirement age or contribution levels $(0.25)$ or instances of reforms that include administrative changes or changes to benefit indexation (0).

\section{Causal conditions}

We have selected causal conditions that take into consideration key institutional and structural socio-economic factors highlighted in the literature. Regarding institutional factors, scholars agree that the strength of key veto players in pension reforms such as the government and the labor movement may affect pension reform outcomes. Therefore, we have built two causal conditions: strong labor movement (SL) and significant legislative fragmentation (LF). To capture the expectations from structuralist and neo-functionalist analysis we have built two other causal conditions: significant unemployment (SU) and significant government deficit (GD). The coding and calibration of these four causal conditions are explained in the annex.

\section{Analysis}

The fsQCA software (http://www.compasss.org) is used to find out the conditions or combination thereof that are sufficient for the outcome to occur, i.e. conditions that must be present for the outcome to occur. This analysis involves two steps. In the first step, a 'truth 
table algorithm' (Ragin 2005) is used to transform the fuzzy-set membership scores for each case into a truth table. This algorithm uses the direct link between the rows of the truth table and the corners of the property space, whereby the latter is the multidimensional space consisting of the logically possible combinations of causal conditions. If there are $\mathrm{k}$ conditions, the property space has $2^{\mathrm{k}}$ corners. In this article, the property space has $2^{4}(=16)$ corners.

In the second stage, the researcher examines the distribution of cases across the corners of the property space (the resulting rows of the truth table) and establishes the degree to which membership in a corner is a subset of the outcome - that is, to what extent a case's placement in a specific combination of conditions is sufficient for the outcome (significant pension reform) to occur (see Ragin 2006: 96). Table 1 Shows the resulting truth table.

\section{Table 1 here}

In this phase, the researcher must look at the "Number" column, which indicates how many cases accord to a specific combination. The researcher must then set a frequency threshold. The present analysis uses a frequency threshold of 1 . Combinations with 0 number of cases are discarded. Subsequently the researcher must look at the consistency column and decide on a threshold to set out which combinations are a subset of the outcome (sufficient) and thus will receive a value of 1 in the outcome column. Consistency ranges from 0 to 1 and it measures the degree to which a causal combination is a subset of the outcome (sufficient) (Rihoux and Ragin, 2009). In general consistency values below 0.8 denote high inconsistency (Rihoux and Ragin, 2009, p. 118). Thus, we choose a consistency cut-off of 0.8 for our analysis. 
As a result of this step the software will simplify, using Boolean algebra, the combinations that are a subset of the outcome and produce a simplified solution with a number of combinations or "routes" for our outcome of interest. The software produces a complex, parsimonious and intermediate solution. In our analysis we use only the complex solution as it is the only one that does not make simplifying assumptions. Simplifying assumptions are statements about the hypothetical outcome of the logical remainders, which are the combinations that may be possible but for which there are no cases. Table 2 reports the fs/QCA software solution:

\section{Table 2 here}

The fsQCA analysis provides values of consistency and coverage for each term of the solution and for the solution as a whole. The fsQCA output also produces an estimate of coverage. Coverage indicates the proportion of membership in the outcome explained by the whole solution or by each term of the solution. As such, the coverage coefficient bears some resemblance to the $\mathrm{R}^{2}$ (coefficient of determination) in regression analysis. The overall coverage of our model is over 0.65 , which indicates that more than 65 percent of instances of the outcome are explained by the four combinations identified in the solution. The software also provides a coverage value for each combination, which includes raw and unique coverage. Raw coverage measures the proportion of memberships in the outcome explained by each term of the solution. Unique coverage measures the proportion of memberships in the outcome explained solely by each individual solution term (memberships that are not covered by other solution terms). Thus, unique coverage is always lower than raw coverage as it is a much restrictive measure. 
The results indicate that significant unemployment is a necessary condition, as it features in all three combinations of causes. Thus, all instances of significant pension reform feature significant unemployment. This lends some support to the literature that focuses on structural socio-economic conditions to explain significant economic and pension reform and argues that unemployment features prominently in instances of pension reform (Huber and Stephens 2001). The results also indicate that unemployment by itself does not lead to significant pension reform as it must be combined with other causal conditions to be sufficient for significant pension reform to occur.

Overall, the results indicate that significant pension reform is a complex phenomenon as it is present when conditions combine in different ways. The fact that unemployment must be combined with other conditions to lead to significant pension reform illustrates the concept of multiple conjunctural causation. The results also illustrate the concept of equifinality as there are three different solutions or "routes" that lead to significant pension reform.

The first solution indicates that unemployment must be combined with the absence of legislative fragmentation to lead to significant pension reform. This provides some support to institutional "veto player" analyses that argue that a less fragmented political system may be more conducive to significant reform (Natali 2004; Orenstein 2000). Yet it also illustrates that a strong government will be compelled to introduce a significant reform if facing a deteriorating structural economic situation marked by persistently high unemployment levels. This corroborates some scholars' views that socio-economic changes can act as triggers to structural reforms but tend to be mediated by institutional conditions (Rodrik 1996; Starke 2006). The second solution illustrates the "structural economic" route to pension reform more 
clearly, as it combines significant unemployment with high government deficit levels. Finally, the third route illustrates that governments are successful in introducing significant pension reform when facing a strong labor movement and a deteriorating economic situation marked by high unemployment. This seems to contradict the assumptions of the power resource theory, which argued that a strong labor movement will typically resist structural reforms. Yet, when combined with a deteriorating structural economic situation, a strong labor movement may be instrumental in supporting significant reform in exchange of specific concessions (Natali and Rhodes 2007).

How well do the three combinations identified in this analysis cover the cases of significant pension reform? To illustrate this Table 3 below shows the fuzzy scores for the outcome and the three casual combinations for each case.

\section{Table 3 here}

Instances of the outcome (values over 0.5 , indicating reforms that are mostly significant or significant) are marked in bold in the first column. ${ }^{2}$ Solutions that are a subset of the outcome (sufficient) are equal or less than the value of the outcome are also marked in bold. However, it should be noted that a high difference between the value of the outcome and a given sufficient causal combination denotes high inconsistency (Ochel and Rohwer 2009, 23; Ragin 2006).

In the case of the Hungarian reform of 1997 that introduced a new mandatory private pillar, we observe that this is explained by the combination of high unemployment and the absence

\footnotetext{
${ }^{2}$ This approach to interpreting the results is consistent with other fsQCA analyses; see for example Vis (2009)
} 
of legislative fragmentation. This is consistent with analyses that have pointed out how, in the context of high unemployment in the 1990s as a result of the transition from state socialism to capitalism, the strong government led by Fidesz (which had a near majority in Parliament itself) and allies, pushed for the reform as part of the package of market-oriented reforms (Müller 1999).

In 14 out of 20 instances of the outcome we identify more than one combination as sufficient, meaning that the outcome can be explained by more than one combination. Using substantive knowledge, we can identify the combination of causal conditions that is more relevant for each case. In the case of the Hungarian reform of 2011, which eliminated the private pillar introduced in 1997, both the combination of significant unemployment with either the lack of legislative fragmentation or high government deficit levels are sufficient to explain this reform. While the absolute majority enjoyed by Fidesz in Parliament cannot be disregarded, scholars have pointed out how the need to reduce pressure on finances coupled with the European Commission's negative response to Hungarian and other European governments' request to exclude the transition costs of pension privatization from debt and deficit accounts led the government to eliminate the private pillar and switch those funds to the Treasury as a "quick fix" to improve its financial position (Simonovits 2011; Datz and Dancsi 2013). Thus the combination of significant unemployment and government deficit seems to better apply to this case.

In the case of the Greek pension reform of 2010, which changed the funding principle of the first public pillar by introducing a sustainability factor, the combination of unemployment with either the lack legislative fragmentation or the existence of a strong labor movement are sufficient to lead to this outcome. A closer look at this case shows that majoritarian electoral 
rules, which provide a 50 seat bonus to the first party, played a significant role in securing Government's support in Parliament. This is consistent with analyses of this reform that showed that there was not much resistance in Parliament to support this package (Gemenis and Nezi 2015).

The Italian pension reform of 1995 changed the benefit calculation of the first pillar by introducing a system of notional accounts where contributions will still be used to pay current pensioners; however, the benefit will now be calculated based on the amount of contributions made while working and life expectancy at retirement, among other conditions. The results show that the combination of significant unemployment with either government deficit or a strong labor movement is sufficient to explain this outcome. Yet, previous analyses have shown that negotiation with the strong labor movement (whose protests led to the resignation of the previous Berlusconi government) was key to reach a consensus for this reform. This was facilitated through specific concessions for the labor movement regarding the administration of the system and the exclusion of older workers from the reform (Natali and Rhodes 2007).

The results in Table 3 also highlight that a combination of causes may be sufficient but highly inconsistent. For example, the UK reform of 2008 that introduced automatic enrolment into private pensions could be explained by any of the three causal combinations. However, there is maximum difference between the value of the outcome and the value of each causal combination, which denotes high inconsistency. Similarly, in the case of the Swedish reform of 1994 that introduced a mandatory private pillar all the three combinations are sufficient. We conclude that other combinations of causes not captured in this study may better explain this reform. 


\section{Discussion and Conclusions}

Pension reforms have attracted scholarly attention and have produced a vast literature based on different theories (new politics of the welfare state, power resources, structuralneofunctionalism) that has identified the factors that may be linked to significant reform. The related literature has also hinted that pension reform processes are complex and may be the result of the combination of different factors (Natali 2004; Anderson and Immergut 2007; Hinrichs 2005). Yet, such analyses have tended to focus on a small number of cases and their explanations are complex.

We have used fsQCA to find out more systematic explanations on the specific combination of causes that may lead to significant pension reform. Our results show three pathways : 1) the presence of significant unemployment combined with the absence of significant legislative fragmentation, 2) the presence of significant unemployment with significant government deficit levels and 3) the presence of significant unemployment with the presence of a strong labor movement.

Our analysis indicates that while structural socio-economic conditions (such as unemployment) may act as triggers, they need to be combined with other specific factors in order to lead to significant pension reform. Certainly, this case has been made before (Rodrik 1996; Starke 2006). Yet, the specific combinations of conditions found in our analysis seem to challenge or, at least complement, some of the assumptions of the main theories on pension reform processes. For example, according to the power resource theory only a weak labor movement would allow the introduction of significant pension reform. As our analysis has shown, facing significant high unemployment levels, a strong labor movement may 
consider lending support to the introduction of paradigmatic changes. This could be as part of a trade-off strategy. The reform adopted in Italy in 1995 (mostly signficant according to our analysis) is a good example: the change in the funding principle of the first pillar from defined benefit to notional defined contribution has been made possible through a trade-off strategy between the government and trade unions, with the latter obtaining concessions such as a long phase-in period of the new system so as to protect older workers, on whose support they mainly rely (Natali and Rhodes 2004).

Furthermore, the finding that unemployment must be combined with the absence of legislative fragmentation, puts into question some of the assumptions of the New Politics of the Welfare state literature, which argued that weak governments may be more successful at passing significant reforms by hiding the blame for their costs. By contrast, our finding seems to indicate that, facing high unemployment levels, strong governments may have it easier to justify significant reforms. This is illustrated by the case of Hungary in 1997, where a fairly strong government introduced a mandatory private pillar as part of the package of marketoriented reforms designed to develop capital markets and address stagnant economic growth and high unemployment in the 1990s. In this way, this finding complements the insights of the "veto player" perspective (Tsebelis 2002) which expects strong governments to be able to pass significant reforms

Finally, the expectations of structural economic theories are further complemented by our finding that the combination of significant high unemployment and government deficit levels leads to significant pension reforms. The elimination of the private pillar in Hungary in 2011 illustrates this finding, albeit we acknowledge that we arrive to this conclusion by using substantive knowledge on this case All in all, we acknowledge the limitations in our analysis 
so further qualitative and quantitative research would be necessary to explore the extent to which the assumptions of well established theories can be challenged and complemented to better understand instances of significant pension reform.

Accounting for multiple conjunctural causation has been a significant motivation for this analysis. Indeed, our analysis has shown that pension reform is the result of the combination of different causes. However, fsQCA is just one method by which we can gain a better understanding of how different causal conditions may combine to explain complex social phenomena. Furthermore, fsQCA is not without its limitations, most notably how to consistently calibrate a complex outcome and a set of causal conditions consistently. Using cases' substantive knowledge is key to address this major concern. We have also shown that fsQCA is not a deterministic method (Schneider and Wagemann $(2012,316)$. With the introduction of parameters of fit such as consistency, we have shown that while solutions may be sufficient, they may not be consistent. This may mean that further qualitative research is needed to understand cases covered by inconsistent sufficient combinations. As we discussed in the case of the significant Swedish 1994 reform and the (mostly significant) UK 2008 pension reforms, all three solutions, while sufficient, are highly inconsistent, thus they cannot properly account for those cases .

Overall, our analysis shows that pension reform is a complex phenomenon. This is consistent with other empirical studies which have found that welfare reforms are explained by the combination of specific conditions (Vis 2009; Gelepithis 2018). As such, our analysis provides support and evidence on the insights of other scholars who advanced the need to consider the combination of different conditions to explain episodes of significant pension reform (Natali 2004; Anderson and Immergut 2007; Hinrichs 2005). We conclude that future 
pension reform research could gain from the insights of our analysis while also considering the limitations of fsQCA and the ways in which these can be addressed.

\section{References}

Abou-Chadi, T. and Immergut, E. M. (2018), 'Recalibrating social protection: Electoral competition and the new partisan politics of the welfare state', European Journal of Political Research, 15 October 2018.

Anderson, K. M. and Immergut, E. M. (2007), 'Sweden: After social democratic hegemony', in Immergut, E., Anderson, K. and Schulze, I. (eds), The handbook of west European pension politics. New York: Oxford University Press: 349-386.

Beland, D. (2009), 'Ideas, institutions, and policy change.' Journal of European Public Policy 16(5): 701-718.

Bonoli, G. (2000), The Politics of Pension Reform. Institutions, Policy Change in Western Europe, Cambridge: Cambridge University Press.

Bonoli, G. and Palier, B. (2007), 'When past reforms open new opportunities: comparing old age insurance reforms in Bismarckian welfare systems', Social Policy and Administration, 41: 6, 555-73.

Brooks, S. (2009), Social Protection and the Market in Latin America: the transformation of Social Security Institutions. Cambridge: Cambridge University Press.

Datz, G. and Dancsi, K. (2013), 'The Politics of Pension Reform Reversal: A Comparative Analysis of Hungary and Argentina', East European Politics, 29(1): 83-100.

Ebbinghaus B. (2011), 'The role of trade unions in European pension reform: From 'old' to 'new politics?' European Journal of Industrial Relations 17(4): 315-331.

Esping-Andersen, G. (1990), The Three Worlds of Welfare Capitalism. Cambridge: Polity Press. 
Eurostat (2017) Eurostat Database

Gallagher, M. (2017), Election indices dataset. Available at: http://www.tcd.ie/Political_Science/staff/michael_gallagher/ElSystems/index.php Gelepithis, M. (2018), 'Three paths to more encompassing supplementary pensions' Journal of Social Policy, 47,3, 603-623.

Gemenis, K. and Nezi, R. (2015), 'Government-Opposition Dynamics during the Economic Crisis in Greece.' The Journal of Legislative Studies 21 (1): 14-34.

Green-Pedersen, C. (2003), 'Small States with Big Success. Party Politics and Governing the Economy in Denmark and the Netherlands 1973-2000', Socio-Economic Review 1, 3: 411-437.

Hall, P.A. (1993) 'Policy Paradigms, Social Learning and the State: the case of economic policymaking in Britain', Comparative Politics, 25(3): 275-296.

Hick, R. (2017), 'Enter the Troika: The politics of social security during Ireland's bailout', Journal of Social Policy. 47,1,1-20.

Hinrichs, K. (2000), 'Elephants on the Move: Patterns of Public Pension Reform in OECD Countries', European Review 8, 353-378.

Hinrichs, K. and Kangas, O. (2005), 'When Is a Change Big Enough to Be a System Shift? Small System-shifting Changes in German and Finnish Pension Policies', Social Policy and Administration, 37(6): 573-591.

Hinrichs, K. (2005) 'New Century-New Paradigm. Pension Reforms in Germany', in Bonoli, G. and Shinkawa (eds.) Ageing and Pension Reform Around the World. Cheltenham: Edward Elgar.

Huber, E. and Stephens, J (2001), Development and Crisis of the Welfare State. Chicago: The University of Chicago Press.

IMF (2017) World Economic Outlook 
Immergut, E., Anderson, K. and Schulze, I. (2007), The Handbook of West European Pension Politics. Oxford: Oxford University Press.

Korpi, W. and Palme, J. (2003), 'New Politics and Class Politics in the Context of Austerity and Globalisation', American Political Science Review 97 (3): 425-46.

Müller, K. (1999), The Political Economy of Pension Reform in Central-Eastern Europe Cheltenham: Edward Elgar.

Myles, J. and Pierson, P. (2001), 'The Comparative Political Economy of Pension Reform', in Pierson, P. (ed.) The New Politics of the Welfare State, Oxford: Oxford University Press.

Natali, D. (2004), 'Europeanization, Policy Arenas, and Creative Opportunism: The Politics of Welfare State Reforms in Italy', Journal or European Public Policy, 11(6): 1077-1096.

Natali, D. and Rhodes, M. (2007), 'The New Politics of Pension Reforms in Continental Europe', in C. Arza and M. Kohli (eds) The Political Economy of Pensions: Politics, Policy Model and Outcomes in Europe, pp. 25-46. London: Routledge.

Ochel, W. and Rohwer, A. (2009), 'Reduction of Employment Protection in Europe: A Comparative Fuzzy-Set Analysis.' CESifo Working Paper, (2828).

OECD (2017) OECD Data

O'Connor, J. and Olson, G. (eds) (1998), Power Resources Theory and The Welfare State: A Critical Approach, Toronto et al: University of Toronto Press.

Orenstein, M. (2011), 'Pension privatization in crisis: Death or rebirth of a global policy trend?', International Social Security Review, 64(3): 65-80

Orenstein, M. (2005) 'The New Pension Reform as Global Policy', Global Social Policy, 5, 2, 175-202.

Orenstein, M. (2000), 'How Politics and Institutions Affect Pension Reform in Three PostCommunist Countries', Policy Research Working Paper 2310,Washington, DC: World Bank. 
Pensions Policy Institute - PPI (2014), Automatic Enrolment Report 3: How will automatic enrolment affect pension saving?

Pierson, P. (2001), 'Post-industrial Pressures on Mature Welfare States,' in Pierson, P. (ed.) The New Politics of the Welfare State. Oxford: Oxford University Press.

Pierson, P. (1996), 'The New Politics of the Welfare State' World Politics 48, 2.

Pierson, P. (1994), Dismantling the Welfare State: Reagan, Thatcher and the Politics of Retrenchment. New York: Cambridge University Press

Ragin, C. (2008), Redesigning Social Inquiry: Fuzzy Sets and Beyond. Chicago and London: The University of Chicago Press.

Ragin, C. (2006), User's guide to fuzzy-set/qualitative comparative analysis 2.0. Tucson, AZ: Department of Sociology, University of Arizona. Available online at: http:// www.u.arizona.edu/ cragin/fsQCA/.

Ragin, C. (2000), Fuzzy Set Social Science. Chicago, IL and London: The University of Chicago Press.

Rihoux, B. and Ragin, C. (eds.) (2009), Configurational Comparative Methods: Qualitative Comparative Analysis (QCA) and Related Techniques. Thousand Oaks, CA: Sage

Rodrik, D. (1996), 'Understanding Economic Policy Reform', Journal of Economic Literature, vol. 34(1): 9-41.

Schmidt, V. (2003), 'How, Where and When does Discourse Matter in Small States' Welfare State Adjustment,' New Political Economy, 8(1), March.

Schmidt, V. and Radaelli, C, (2004), 'Policy Change and Discourse in Europe: Conceptual and Methodological Issues', West European Politics, 27(2): 183-210.

Schneider, C. and Wagemann, C. (2012), Set Theoretic Methods for the Social Sciences. A guide to Qualitative Comparative Analysis. Cambridge, UK: Cambridge University Press. 
Simonovits, A. (2011) 'The Mandatory Private Pension Pillar in Hungary: An Obituary', International Social Security Review 64(3): 81-98.

Sotiropoulos, D. (2004), 'The EU's Impact on the Greek Welfare State: Europeanization on paper?' Journal of European Social Policy 14 (3):267-284.

Starke, P. (2006), 'The Politics of Welfare State Retrenchment: A Literature Review', Social Policy \& Administration, 40,1,104-120.

Theodoropoulou, S. (20014), 'Has the EU become more intrusive in shaping national welfare state reforms? Evidence from Greece and Portugal' ETUI Working Paper 2014.04

Tsebelis, G. (2002), Veto Players: How Political Institutions Work. Princeton University Press.

Vis, B. (2009), 'Governments and Unpopular Social Policy Reform: Biting the Bullet or Stearing Clear.' European Journal of Political Research 48 (1): 31-57.

Visser J. (2009), 'The Quality of Industrial Relations and the Lisbon Strategy.' In: European Commission (ed.) Industrial Relations in Europe 2008. Luxembourg: Office for Official Publications of the European Communities.

Visser, J (2016) ICTWSS: Database on Institutional Characteristics of Trade Unions, Wage Setting, State Intervention and Social Pacts in 34 countries Available: http://www.uvaaias.net/208

World Bank (2017) World Development Indicators

Table 1: Truth Table

\section{Causal conditions}

\begin{tabular}{ccccccc}
\hline LF & GD & SU & SL & SPR & $\boldsymbol{N}$ & Consistency \\
\hline 0 & 0 & 1 & 0 & 1 & 1 & 0.94 \\
1 & 1 & 1 & 0 & 1 & 1 & 0.93 \\
0 & 0 & 1 & 1 & 1 & 1 & 0.88
\end{tabular}




\begin{tabular}{lllllll}
1 & 0 & 1 & 1 & 1 & 3 & 0.87 \\
1 & 1 & 1 & 1 & 1 & 2 & 0.84 \\
0 & 1 & 1 & 0 & 1 & 2 & 0.83 \\
0 & 1 & 1 & 1 & 1 & 3 & 0.82 \\
1 & 1 & 0 & 1 & 0 & 3 & 0.75 \\
0 & 0 & 0 & 0 & 0 & 4 & 0.74 \\
0 & 1 & 0 & 0 & 0 & 4 & 0.62 \\
0 & 1 & 0 & 1 & 0 & 4 & 0.55 \\
1 & 0 & 0 & 1 & 0 & 13 & 0.47 \\
1 & 0 & 0 & 0 & 0 & 6 & 0.41 \\
0 & 0 & 0 & 1 & - & 0 & \\
1 & 0 & 1 & 0 & - & 0 & \\
1 & 1 & 0 & 0 & - & 0 & \\
\hline
\end{tabular}

Table 2: fsQCA solution

\begin{tabular}{llll}
\hline & $\begin{array}{l}\text { Raw } \\
\text { Coverage }\end{array}$ & $\begin{array}{l}\text { Unique } \\
\text { Coverage }\end{array}$ & Consistency \\
\hline $\mathrm{UN}^{*} \sim \mathrm{LF}$ & 0.459 & 0.038 & 0.837 \\
$\mathrm{UN} * \mathrm{GD}$ & 0.437 & 0.025 & 0.756 \\
$\mathrm{UN} * \mathrm{SL}$ & 0.500 & 0.088 & 0.816 \\
\hline
\end{tabular}

solution coverage: 0.658

solution consistency: 0.789

Table 3: Membership scores of cases

\begin{tabular}{ccccc}
\hline CASE & Outcome: SPR & UN* $\sim \mathbf{L F}$ & UN*GD & UN*SL \\
\hline GR1990 & 0.25 & 0.25 & 0.25 & 0.25 \\
GR1991 & 0.25 & 0.25 & 0.25 & 0.25 \\
GR1992 & 0.25 & 0.25 & 0.25 & 0.25 \\
GR1999 & 0 & 1 & 0.75 & 1 \\
GR2002 & $\mathbf{0 . 7 5}$ & $\mathbf{0 . 7 5}$ & $\mathbf{0 . 7 5}$ & $\mathbf{0 . 7 5}$ \\
GR2008 & 0.25 & 0.25 & 0.25 & 0.25 \\
GR2010 & $\mathbf{0 . 7 5}$ & $\mathbf{0 . 7 5}$ & 1 & $\mathbf{0 . 7 5}$ \\
GR2011 & 0.25 & 0.75 & 1 & 0.25 \\
GR2012 & $\mathbf{0 . 7 5}$ & 0 & 1 & $\mathbf{0 . 2 5}$ \\
ITA92 & $\mathbf{0 . 7 5}$ & 0 & $\mathbf{0 . 2 5}$ & $\mathbf{0 . 2 5}$ \\
ITA95 & $\mathbf{0 . 7 5}$ & 0 & $\mathbf{0 . 7 5}$ & $\mathbf{0 . 7 5}$
\end{tabular}




\begin{tabular}{|c|c|c|c|c|}
\hline CASE & Outcome: SPR & $\mathbf{U N} * \sim \mathbf{L F}$ & UN*GD & $\mathbf{U N} * \mathbf{S L}$ \\
\hline ITA97 & 0.25 & 0 & 0.75 & 0.75 \\
\hline ITA04 & 0.75 & 0 & 0.25 & 0.25 \\
\hline ITA09 & 0.25 & 0.25 & 0 & 0.25 \\
\hline ITA10 & 0.25 & 0.25 & 0.25 & 0.25 \\
\hline ITA11 & 0.75 & 0.25 & 0.25 & 0.25 \\
\hline HU97 & 1 & 0.5 & 0.25 & 0.25 \\
\hline HU10 & 0.75 & 0.75 & 0.25 & 0 \\
\hline HU11 & 1 & 0.75 & 0.75 & 0 \\
\hline SWE92 & 0 & 0 & 0 & 0 \\
\hline SWE94 & 1 & 0.25 & 0.25 & 0.25 \\
\hline SWE98 & 0.25 & 0.25 & 0 & 0.25 \\
\hline SWE01 & 0 & 0 & 0 & 0 \\
\hline GER97 & 0.75 & 0.25 & 0.25 & 0.75 \\
\hline GER98 & 0.75 & 0.25 & 0 & 0.75 \\
\hline GER01 & 0.75 & 0.25 & 0 & 0.25 \\
\hline GER04 & 0.75 & 0.25 & 0.25 & 0.75 \\
\hline GER07 & 0.25 & 0 & 0 & 0.25 \\
\hline GER09 & 0 & 0 & 0 & 0.25 \\
\hline SWZ94 & 0 & 0 & 0 & 0 \\
\hline SWZ95 & 0.25 & 0 & 0 & 0 \\
\hline SWZ03 & 0.25 & 0 & 0 & 0 \\
\hline SWZ10 & 0 & 0 & 0 & 0 \\
\hline NL87 & 0 & 0.25 & 0.25 & 0.25 \\
\hline NL92 & 0 & 0 & 0 & 0 \\
\hline NL94 & 0.75 & 0.25 & 0 & 0.25 \\
\hline NL97 & 0 & 0 & 0 & 0.25 \\
\hline NL04 & 0.25 & 0 & 0 & 0 \\
\hline NL06 & 0 & 0 & 0 & 0 \\
\hline UK86 & 0.75 & 0.75 & 0 & 0.75 \\
\hline UK95 & 0.25 & 0.25 & 0.25 & 0.25 \\
\hline UK99 & 0.75 & $\mathbf{0}$ & 0 & $\mathbf{0}$ \\
\hline UK04 & 0 & 0 & 0 & 0 \\
\hline UK07 & 0.25 & 0 & 0 & 0 \\
\hline UK08 & 0.75 & $\mathbf{0}$ & 0 & 0 \\
\hline UK11 & 0.25 & 0.25 & 0.25 & 0 \\
\hline UK13 & 0.25 & 0.25 & 0.25 & 0 \\
\hline UK14 & 0.75 & 0.25 & 0.25 & 0 \\
\hline
\end{tabular}

Annex

Table A1: calibration of outcome SPR

\begin{tabular}{|l|l|l|l|l|}
\hline $\begin{array}{l}\text { Fuzzy set } \\
\text { value }\end{array}$ & \multicolumn{1}{c|}{0} & 0.25 & 0.75 & 1 \\
\hline Changes & $\begin{array}{l}\text { The reform must } \\
\text { contain at least one of }\end{array}$ & $\begin{array}{l}\text { The reform must } \\
\text { contain at least one }\end{array}$ & $\begin{array}{l}\text { The reform must contain at } \\
\text { least one of the following: }\end{array}$ & $\begin{array}{l}\text { The reform must } \\
\text { contain: }\end{array}$ \\
\hline
\end{tabular}




\begin{tabular}{|c|c|c|c|c|}
\hline $\begin{array}{l}\text { that must } \\
\text { be present }\end{array}$ & $\begin{array}{l}\text { the following: } \\
\text { - Administrative } \\
\text { changes such as } \\
\text { changes to } \\
\text { regulatory } \\
\text { bodies } \\
\text { - Changes to } \\
\text { benefit } \\
\text { indexation } \\
\text { mechanism }\end{array}$ & $\begin{array}{l}\text { of the following: } \\
\text { - Increase in } \\
\text { retirement age } \\
\text { - Increase in } \\
\text { contribution } \\
\text { rates }\end{array}$ & $\begin{array}{l}\text { - Change in funding } \\
\text { principle for first pillar } \\
\text { - Introduction/expansion } \\
\text { of a non- mandatory } \\
\text { private pillar }\end{array}$ & $\begin{array}{l}\text { - Introduction/ } \\
\text { Elimination of } \\
\text { a mandatory } \\
\text { private pillar }\end{array}$ \\
\hline
\end{tabular}

To calibrate each case for the outcome of SPR we first look at whether a given reform case introduces or eliminates a mandatory private pillar. If it does, then it is given a fuzzy set value of 1 , although it is sensical to assume that it may be accompanied by other changes like increases in retirement age, etc, which are not taking into consideration if the reform features the introduction or elimination of a private pillar. If the reform does not introduces/eliminate a private pillar, then we consider whether it introduces or expands a non-mandatory private pillar or if it changes the funding principle of the first public pillar. If it does, then it receives a fuzzy set value of 0.75 . If it does not, then we look at whether it features at least one of the policy elements listed above to be given a fuzzy set value of 0.25 or 0 .

\section{Coding and calibration of causal conditions:}

1) Strong labour movement (SL). For this causal condition we use data from Visser (2016) on the institutional characteristics of trade unions. We consider two key variables from this dataset to build the SL causal condition: union density and wage bargaining coverage. Union density measures the net union membership as a proportion of wage and salary earners in employment. ${ }^{3}$ Collective bargaining coverage measures the number of employees covered by wage bargaining agreements as a proportion of all wage and salary earners in employment

\footnotetext{
${ }^{3}$ Net union membership is the total union membership minus union members outside the active, dependent and employment labour force (i.e., retired workers, independent workers, students and unemployed). See Visser (2016, p. 15).
} 
with the right to bargaining (Visser 2009, 15). We consider that the overall strength of the labor movement depends more on the coverage of the collective wage agreements they can sign than on the number of workers affiliated to them, albeit this cannot be totally disregarded. This is because the existence of wide-ranging collective agreement will surely cover workers who are not members of a trade union. Consistent with this approach we weight the raw values of these two variables in the year a reform is adopted in the following way: union density is weighted by $1 / 3$ and collective bargaining coverage is weighted by $2 / 3$. The added weighted value is then converted into a five fuzzy set value casual condition.

To calibrate the fuzzy set values we looked at the distribution of the data and identified gaps of more than 2 percentage points. These were at $65 \%$ at the top of the distribution and at $30 \%$ at the bottom. Therefore, total values of $65 \%$ or more are considered to be "fully in the set" of strong labor movements and given a fuzzy set value of 1 . Total values of $30 \%$ or less are "fully out of the set" of strong labor movements and given a fuzzy set value of 0 . The crossover point is set for a total value of $50 \%$. Total values of more than $30 \%$ but less than $50 \%$ are "almost out of the set" and receive a value of 0.25 . Total values of more than $50 \%$ but less than 65 are "almost in the set" and receive a value of 0.75 .

2) Significant legislative fragmentation (LF). This causal condition captures the degree of fragmentation in a given polity. A significantly fragmented legislature will give place to weaker governments than a non fragmented one as a coalition will be necessary to form government. As our cases include countries with two chambers, we focus on the chamber that wields the majority of power in the law-making process and whose membership is key for the formation of Government (i.e., the Commons in the case of the UK, the Deputies Chamber in Italy, the Bundestag in Germany and so on). 
We use the effective number of parties' seats (number of parties with seats) in the main chamber in the year in which the pension reform started to be treated to construct a fuzzy set condition of legislative fragmentation. ${ }^{4}$ This data comes from Gallagher (2017). ${ }^{5}$ The higher the number of effective party seats the higher the fragmentation in a given polity and in its government.

Our understanding of significant fragmentation is one in which coalitions are hard to achieve. A solid three party system may have a tendency towards a bipartisan logic if the center is occupied by a party open to form alliances. A political system with four or more effective parties with seats could make such behaviour more difficult given the need to provide specific concessions to more than one party (Laakso and Taagepera 1979). Therefore, we assume that an effective number of party seats of 4 or more is "fully in the set" of significant fragmentation and receives a fuzzy set value of 1 . An effective number of parties of 2.5 or less is "fully out of the set" of significant fragmentation and it receives a value of 0 . An effective number of parties of 3 is "neither in nor out" and receives a value of 0.5. An effective number of more than 2.5 and less than 3 will be "mostly out of the set" of significant fragmentation and receives a fuzzy set value of 0.25 . An effective number of more than 3 and less than 4 is "almost in the set" and receives a value of 0.75 .

Many scholars (Huber and Ragin 2001; Weyland 2002) have highlighted that unemployment rates significantly affect the sustainability of pension systems and thus lead to reforms. Furthermore,pension spending represents the most significant outlay in government spending (World Bank 1994; Natali 2004). It follows that high unemployment and also a significant

\footnotetext{
${ }^{4}$ More specifically, we took the number corresponding to the last election before a reform was introduced as we assume that the government composition is a result of such election
} 
government deficit may prompt the need for reform as it will put a significant burden on the government to finance the pension system. Our two structural socio-economic causal conditions are therefore as follows:

3) Significant unemployment (SU). Any significant increase in unemployment puts pressure on the financing of the system. However, we consider that such effect is not immediate as time may pass until the situation gets really serious and the government decides to carry out a pension reform. Thus, we look at the average unemployment rate of the four quarters before a reform is introduced. The sources for these data are World Bank (2017), Eurostat (2017) and OECD (2017).

Selecting a cut-off for full membership in the set of high unemployment is context specific. The cut-off could be quite different if we were looking at the USA, with its more deregulated labour market than continental Europe. To calibrate this outcome we have looked at the distribution of the data to see gaps of more than $2 \%$. These have been identified at $12 \%$ at the top of the distribution and at $6 \%$ at the bottom. Therefore, a fuzzy set value of 1 is given to cases with an average unemployment rate of $12 \%$ or more. Cases with average unemployment rates of $6 \%$ or less are considered to be "fully out of the set" of significant unemployment and thus given a fuzzy set value of 0 . The cross-over fuzzy set value of 0.5 is set at $9 \%$. Thus cases with unemployment rate values of more than $9 \%$ but less than $12 \%$ are given a fuzzy set value of 0.75 and cases with unemployment rates of more than $6 \%$ but less than $9 \%$ are given a fuzzy set value of 0.25 .

4) Significant government deficit (GD). Given that pension payments constitute the single most important item of government spending in advanced industrialized countries, we 
assume that high levels of government budget deficit increase the likelihood of adopting a significant reform. As with unemployment, we acknowledge that some time may pass until the government decides to address this by proposing a significant pension reform. Thus, we consider the value of government budget balance in the year prior to the introduction of a pension reform proposal to construct a fuzzy-set causal condition. This data comes from IMF (2017).

A fuzzy set value of 1 and thus "fully in the set" of significant government deficit is given to cases with deficit values of $7 \%$ of GDP and over. Cases with deficits of $3 \%$ or less are considered to be "fully out of the set" of significant deficit as this equals to the threshold set out in the EU Stability and Growth Pact. The 0.5 cross-over value is given to cases with deficits of $5 \%$ of GDP. Therefore, cases with budget deficits of more than $3 \%$ of GDP but less than $5 \%$ are given a fuzzy set value of 0.25 and cases with deficit values of more than $5 \%$ but less than $7 \%$ are given a fuzzy set value of 0.75 . 
Table A2: Fuzzy set values for the outcome and causal conditions

\begin{tabular}{|c|c|c|c|c|c|c|c|}
\hline Country & Year & Reform content & SPR & SL & $\mathbf{L F}$ & SU & GD \\
\hline Greece & 1990 & $\begin{array}{l}\text { Increase in retirement age to } 60 \\
\text { (women) and } 65 \text { (men) } \\
\text { Increase in minimum contribution } \\
\text { periods } \\
\text { Tightening eligibility for invalidity } \\
\text { pension } \\
\text { Increase in reference period from } 2 \\
\text { to } 5 \text { years } \\
\text { Increase in contribution ceiling } \\
\text { Pension indexation changed } \\
\text { Introduction of benefit reductions } \\
\text { for early retirement } \\
\text { Re-introduction of contributions for } \\
\text { public servants } \\
\text { Abolition of special funds for } \\
\text { banks, telecommunication, } \\
\text { electricity and public transport was } \\
\text { not enacted as originally envisioned }\end{array}$ & 0.25 & 1 & 0 & 0.25 & 1 \\
\hline Greece & 1991 & $\begin{array}{l}\text { Higher retirement age for women } \\
\text { and women with young children } \\
\text { Extension of reference period to the } \\
\text { whole working career } \\
\text { Changes in the level of invalidity } \\
\text { pensions } \\
\text { Law } 1976 / 91 \\
\text { Higher retirement age for women } \\
\text { and women with young children } \\
\text { Extension of reference period to the } \\
\text { whole working career } \\
\text { Changes in the level of invalidity } \\
\text { pensions } \\
\text { Reduction of benefit ceilings }\end{array}$ & 0.25 & 1 & 0 & 0.25 & 1 \\
\hline Greece & 1992 & $\begin{array}{l}\text { Harmonization of eligibility } \\
\text { conditions } \\
\text { Changes in financing: increase in } \\
\text { contribution rates } \\
\text { Harmonization of male and female } \\
\text { retirement ages to } 65 \\
\text { New system for new entrants after } \\
1.1 .1993 \\
\text { Contribution increase for civil } \\
\text { servants and self-employed } \\
\text { Introduction of maximum } \\
\text { replacement rate of } 60 \% \text { for main }\end{array}$ & 0.25 & 1 & 0 & 0.25 & 1 \\
\hline
\end{tabular}




\begin{tabular}{|c|c|c|c|c|c|c|c|}
\hline Country & Year & Reform content & SPR & SL & LF & SU & GD \\
\hline & & $\begin{array}{l}\text { pension and } 20 \% \text { for supplementary } \\
\text { pensions }\end{array}$ & & & & & \\
\hline Greece & 1999 & $\begin{array}{l}\text { Merger of several insurance funds } \\
\text { for self-employed and in the public } \\
\text { sector } \\
\text { Changes in survivors' pension } \\
\text { Changes in pension accumulation } \\
\text { rules }\end{array}$ & 0 & 1 & 0 & 1 & 0.75 \\
\hline Greece & 2002 & $\begin{array}{l}\text { Introduction of legislative } \\
\text { framework for the (voluntary) } \\
\text { creation of occupational capital- } \\
\text { funded pension insurance managed } \\
\text { by the social partners } \\
\text { Harmonization of replacement rate } \\
\text { to } 70 \% \text { for both private and public } \\
\text { sector } \\
\text { Extension of reference period for } \\
\text { public sector from last salary to best } \\
5 \text { of last } 10 \text { years } \\
\text { Establishment of the National } \\
\text { Actuarial Authority and } \\
\text { introduction of voluntary II pillar } \\
\text { pensions }\end{array}$ & 0.75 & 0.75 & 0 & 0.75 & 0.75 \\
\hline Greece & 2008 & $\begin{array}{l}\text { Merging of primary funds into } 5 \\
\text { and of auxiliary into } 8 \\
\text { IKA (primary pensions)-uniformity } \\
\text { of rules to all merged funds } \\
\text { (phased-in) } \\
\text { Incentives for working longer } \\
\text { (increment in pensions for those } \\
\text { working beyond 60, b1993 and } \\
\text { beyond } 65 \text { a.1993) } \\
\text { Age limit for early retirement } \\
\text { tightened and (since } 2013 \text { ) } 58 \text { years } \\
\text { for those with } 37 \text { years of } \\
\text { employment } \\
\text { Increase in retirement age for } \\
\text { women with long phase-in period }\end{array}$ & 0.25 & 0.75 & 0.25 & 0.25 & 0.75 \\
\hline
\end{tabular}




\begin{tabular}{|c|c|c|c|c|c|c|c|}
\hline Country & Year & Reform content & SPR & SL & LF & SU & GD \\
\hline Greece & 2010 & $\begin{array}{l}\text { Introduction of basic pension } \\
\text { (quasi-universal) from } 2015 \\
\text { onwards- means-tested for insured } \\
\text { and those with insufficient } \\
\text { employment record } \\
\text { Changes to indexation formula } \\
\text { Introduction of sustainability factor } \\
\text { From } 2021 \text { adjustment of pension } \\
\text { retirement age on the basis of life } \\
\text { expectancy } \\
\text { Harmonization of retirement age at } \\
65 \text { for both men and women } \\
\text { Retirement allowed with the } \\
\text { completion of } 40 \text { years of work, yet } \\
\text { only if they have reached } 60 \text { years } \\
\text { Early retirement is set at } 60 \text { years } \\
\text { Pension benefit calculated on life- } \\
\text { time earnings (instead of last } 5 \\
\text { years before retirement) } \\
\text { Replacement rate reduced from } \\
70 \% \text { to } 34 \% \text { for } 35 \text { years of work } \\
\text { Rationalization through } \\
\text { amalgamation of funds }\end{array}$ & 0.75 & 0.75 & 0.25 & 1 & 1 \\
\hline Greece & 2011 & $\begin{array}{l}\text { Introduction of (EKAS) Pensioners' } \\
\text { Social Solidarity Supplement } \\
\text { from 1.1.2011: } \\
\text { Minimum age } 60 \text { years }\end{array}$ & 0.25 & 0.25 & 0.25 & 1 & 1 \\
\hline Greece & 2012 & $\begin{array}{l}\text { Creation of single supplementary } \\
\text { fund (ETEA): } \\
\text { Public law body with administrative } \\
\text { and financing organization } \\
\text { Notional defined contribution } \\
\text { system (NDC) } \\
\text { Main sources of funding: employer } \\
\text { and employee contributions } \\
\text { Minimum years for the award of } \\
\text { pension: } 15\end{array}$ & 0.75 & 0.25 & 1 & 1 & 1 \\
\hline
\end{tabular}




\begin{tabular}{|c|c|c|c|c|c|c|c|}
\hline Country & Year & Reform content & SPR & SL & $\mathbf{L F}$ & SU & GD \\
\hline Italy & 1992 & $\begin{array}{l}\text { (D.lgs. 503/92) } \\
\text { Retirement age raised from } 55 \text { to } 60 \\
\text { (female) and from } 60 \text { to } 65 \text { (male) } \\
\text { Benefit calculation formula: } \\
2 \text { from last } 5 \text { (private sector) \& last } \\
\text { month (public sector) to } 10 \text { for } \\
\text { those with at least } 15 \text { years of } \\
\text { contributions Entire working career } \\
\text { for new entrants } \\
\text { Indexation mechanism: from wages } \\
\text { to prices } \\
\text { Lengthening of minimum } \\
\text { qualifying period for standard old- } \\
\text { age pension from } 15 \text { to } 20 \text { years } \\
\text { Phasing-out of baby pensions for } \\
\text { public employees for public } \\
\text { employees } \\
\text { Harmonization of public sector } \\
\text { seniority pensions with private } \\
\text { sector } \\
\text { Lengthening of minimum } \\
\text { qualifying period for seniority } \\
\text { pensions from } 35 \text { to } 36 \text { years } \\
\text { Reduction of accrual rates for } \\
\text { workers with higher wages } \\
\text { D/Lgs } 124 / 93 \text { - II pillar } \\
\text { Legal framework for open and } \\
\text { closed pension funds in the II and } \\
\text { III pillars. }\end{array}$ & 0.75 & 1 & 1 & 0.25 & 1 \\
\hline Italy & 1995 & $\begin{array}{l}\text { Change from final salary to } \\
\text { Notional Defined Contribution). } \\
\text { Gradual phasing } \\
\text { Flexible retirement: } 57-65 \text { years } \\
\text { Seniority pensions: gradual increase } \\
\text { of min qualifying period from } 35 \text { to } \\
40 \text { years } \\
\text { Increase in contribution rates } \\
\text { Tax incentives for supplementary } \\
\text { second pillar pensions }\end{array}$ & 0.75 & 1 & 1 & 0.75 & 1 \\
\hline Italy & 1997 & $\begin{array}{l}\text { Indexation mechanism: } 1 \text { year } \\
\text { freeze } \\
\text { Increase of basic pensions } \\
\text { Tightening of conditions for } \\
\text { seniority pensions }\end{array}$ & 0.25 & 1 & 1 & 0.75 & 0.75 \\
\hline
\end{tabular}




\begin{tabular}{|c|c|c|c|c|c|c|c|}
\hline Country & Year & Reform content & SPR & SL & $\mathbf{L F}$ & SU & GD \\
\hline Italy & 2004 & $\begin{array}{l}\text { Fixed and higher retirement age in } \\
\text { the first pillar: } 65 \text { for men and } 60 \\
\text { for women } \\
\text { Introduction of bonus for deferred } \\
\text { retirement } \\
\text { Introduction of an extra } 3 \% \text { tax on } \\
\text { very high pensions } \\
\text { Second Pillar: TfR transfer with the } \\
\text { 'silent assent' formula- in the } \\
\text { default option }\end{array}$ & 0.75 & 0.75 & 1 & 0.25 & 0.25 \\
\hline Italy & 2009 & $\begin{array}{l}\text { Equalisation of female retirement } \\
\text { age in the public sector from } 60 \text { to } \\
65 \text { by } 2018 \\
\text { Increase in legal retirement age } \\
\text { (postponed for 2015)- adjusted to } \\
\text { change sin life expectancy over past } \\
5 \text { years }\end{array}$ & 0.25 & 1 & 0.75 & 0.25 & 0 \\
\hline Italy & 2010 & $\begin{array}{l}\text { Retirement age harmonized } \\
\text { (male/female-public sector) in } 2012 \\
\text { Introduction of automatic link of } \\
\text { eligibility conditions to } \\
\text { demographic trends }\end{array}$ & 0.25 & 1 & 0.75 & 0.25 & 0.75 \\
\hline Italy & 2011 & $\begin{array}{l}\text { Abolition of seniority pensions } \\
\text { Changes to flexible retirement } \\
\text { Indexation: Temporary freeze for } \\
2012-2013 \text { for pensions above } 1400 \\
\text { gross/month } \\
\text { Shortened phasing in of the NDC } \\
\text { system } \\
\text { Introduction of minimum } \\
\text { contribution period for a full } \\
\text { pension: } 20 \text { years }\end{array}$ & 0.75 & 1 & 0.75 & 0.25 & 0.25 \\
\hline Hungary & 1997 & $\begin{array}{l}\text { I PILLAR } \\
\text { Increase (in steps) of retirement age } \\
\text { for full pension } \\
\text { Reductions (from } 2013 \text { onwards) } \\
\text { for those choosing to retire before } \\
\text { full benefit age } \\
\text { Increase of entry benefits for those } \\
\text { delaying retirement beyond full } \\
\text { benefit age } \\
\text { NEW II PILLAR } \\
\text { Mandatory for new entrants, } \\
\text { optional for old ones }\end{array}$ & 1 & 0.25 & 0.25 & 0.5 & 0.25 \\
\hline
\end{tabular}




\begin{tabular}{|c|c|c|c|c|c|c|c|}
\hline Country & Year & Reform content & SPR & SL & $\mathbf{L F}$ & SU & GD \\
\hline & & $\begin{array}{l}8 \% \text { of gross wage to be channelled } \\
\text { to new pillar }\end{array}$ & & & & & \\
\hline Hungary & 2010 & $\begin{array}{l}\text { Temporary suspension of transfers } \\
\text { to the second private pillar } \\
\text { Introduction of right to exit the II } \\
\text { pillar (those who remained would } \\
\text { have to pay higher contributions } \\
\text { and would lose their right to all } \\
\text { entitlements that will accrue in the I } \\
\text { pillar after 2011) }\end{array}$ & 0.75 & 0 & 0 & 0.75 & 0.25 \\
\hline Hungary & 2011 & $\begin{array}{l}\text { Elimination of II Pillar; } \\
\text { accumulated funds transferred to } \\
\text { the social security fund }\end{array}$ & 1 & 0 & 0 & 0.75 & 0.75 \\
\hline Sweden & 1992 & Changes to indexation mechanism & 0 & 1 & 1 & 0 & 0 \\
\hline Sweden & 1994 & $\begin{array}{l}\text { Guarantee pension (non- } \\
\text { contributory, tax finance for those } \\
\text { with low pension entitlements or no } \\
\text { income) - replaces basic pension } \\
\text { and pension supplement } \\
\text { Payable from the age of } 65 \\
\text { Introduction of a Notional Defined } \\
\text { Contribution system for the first } \\
\text { pillar } \\
\text { Retirement age: flexible, benefits } \\
\text { can be drawn from the age of } 61 \\
\text { Changes to indexation of benefits } \\
\text { accrued and in payment } \\
\text { Introduction of a mandartory } \\
\text { second pillar of individual private } \\
\text { accounts }\end{array}$ & 1 & 1 & 0.75 & 0.25 & 1 \\
\hline Sweden & 1998 & $\begin{array}{l}\text { Increase in contribution rates to } \\
\text { private second pillar from } 2 \text { to } 2.5 \% \\
\text { of qualifying wages }\end{array}$ & 0.25 & 1 & 0.75 & 0.25 & 0 \\
\hline Sweden & 2001 & $\begin{array}{l}\text { SEK } 170 \text { bn transferred from AP } \\
\text { funds to the State to cover transition } \\
\text { costs }\end{array}$ & 0 & 1 & 1 & 0 & 0.25 \\
\hline Germany & 1997 & Changes to the benefit calculation & 0.75 & 0.75 & 0.75 & 0.75 & 0.25 \\
\hline
\end{tabular}




\begin{tabular}{|c|c|c|c|c|c|c|c|}
\hline Country & Year & Reform content & SPR & SL & $\mathbf{L F}$ & SU & GD \\
\hline & & $\begin{array}{l}\text { formula: introduction of } \\
\text { demographic (life expectancy) } \\
\text { adjustment factor in pension } \\
\text { indexation formula (expected to } \\
\text { result in a reduction of replacement } \\
\text { rate from } 70 \% \text { to } 64 \% \text { in the long } \\
\text { run) } \\
\text { Increase in retirement age for } \\
\text { disability pensions (from } 60 \text { to } 63 \text { ) }\end{array}$ & & & & & \\
\hline Germany & 1999 & $\begin{array}{l}\text { Abolishment of demographic } \\
\text { adjustment factor } \\
\text { Compulsory coverage for marginal } \\
\text { employment (atypical employment) }\end{array}$ & 0.75 & 0.75 & 0.75 & 0.75 & 0 \\
\hline Germany & 2001 & $\begin{array}{l}\text { Replacement of the current PAYG } \\
\text { funded system with a dual one } \\
\text { comprising a) a reformed PAYG } \\
\text { system and b) a private personal } \\
\text { pension } \\
\text { I PILLAR } \\
\text { Benefit calculation formula: based } \\
\text { on average gross earnings } \\
\text { Introduction of contribution rate } \\
\text { ceilings ( } 20 \% \text { up to } 2020 \text { and } 22 \% \\
\text { up to } 2030) \\
\text { Introduction of means-tested social } \\
\text { assistance minimum pension } \\
\text { II PILLAR } \\
\text { Introduction of voluntary personal } \\
\text { pensions. }\end{array}$ & 0.75 & 0.75 & 0.75 & 0.25 & 0 \\
\hline Germany & 2004 & $\begin{array}{l}\text { Benefit calculation formula: } \\
\text { introduction of sustainability factor } \\
\text { formula }\end{array}$ & 0.75 & 0.75 & 0.75 & 0.75 & 0.25 \\
\hline Germany & 2007 & $\begin{array}{l}\text { Increase in mandatory retirement } \\
\text { age to } 67 \text { from } 65 \text { ( } 69 \text { by } 2029)\end{array}$ & 0.25 & 0.25 & 1 & 0.25 & 0 \\
\hline Germany & 2009 & $\begin{array}{l}\text { Suspension of current indexation } \\
\text { formula as an exchange for not } \\
\text { reducing pension benefits (as a } \\
\text { result of the crisis) }\end{array}$ & 0 & 0.25 & 1 & 0.25 & 0 \\
\hline Switzerland & 1994 & $\begin{array}{l}\text { II PILLAR } \\
\text { Guarantee of individual pension } \\
\text { savings in case of labour market } \\
\text { mobility } \\
\text { No dissolution of pension savings } \\
\text { for women in case of marriage } \\
\text { Splitting of savings between } \\
\text { spouses in case of divorce }\end{array}$ & 0 & 0.25 & 1 & 0 & 0.25 \\
\hline
\end{tabular}




\begin{tabular}{|c|c|c|c|c|c|c|c|}
\hline Country & Year & Reform content & SPR & SL & LF & SU & GD \\
\hline Switzerland & 1995 & $\begin{array}{l}\text { I PILLAR } \\
\text { Changes in Basic Pension Scheme } \\
\text { (AHV/AVS) } \\
\text { Increase in retirement age for } \\
\text { women from } 62 \text { to } 64 \\
\text { Flexible retirement age } \\
\text { Splitting of contributions and } \\
\text { pensions between spouses and } \\
\text { educational pension credits }\end{array}$ & 0.25 & 0.25 & 1 & 0 & 0 \\
\hline Switzerland & 2003 & $\begin{array}{l}\text { I PILLAR } \\
11 \text { th reform of the basic pension } \\
\text { scheme AHV/AVS (reform failed } \\
\text { in direct democratic referendum) }\end{array}$ & 0.25 & 0.25 & 1 & 0 & 0 \\
\hline Switzerland & 2010 & $\begin{array}{l}\text { Changes to occupational pensions. } \\
\text { This was rejected in a } \\
\text { referendum so was not } \\
\text { implemented }\end{array}$ & 0 & 0.25 & 1 & 0 & 0 \\
\hline Netherlands & 1987 & $\begin{array}{l}\text { Improved portability and protection } \\
\text { of accumulated pension rights in } \\
\text { occupational pensions }\end{array}$ & 0 & 0.75 & 0.75 & 0.25 & 0.25 \\
\hline Netherlands & 1992 & $\begin{array}{l}\text { Changes to benefit indexation in } \\
\text { occupational second pillar pensions }\end{array}$ & 0 & 0.75 & 0.75 & 0 & 0 \\
\hline Netherlands & 1994 & $\begin{array}{l}\text { Further change to occupational } \\
\text { pensions' indexation rules. This led } \\
\text { to change occupational schemes } \\
\text { from final salary Defined Benefit } \\
\text { (DB) to career average DB and to } \\
\text { conditional Defined Contribution } \\
\text { schemes (CDC). }\end{array}$ & 0.75 & 0.75 & 0.75 & 0.25 & 0 \\
\hline Netherlands & 1997 & $\begin{array}{l}\text { Increase in upper limit of first pillar } \\
\text { AOW contribution of } 16.5 \% \\
\text { Establishment of AOW reserve } \\
\text { fund (to help finance future } \\
\text { pensions) }\end{array}$ & 0 & 0.75 & 1 & 0.25 & 0 \\
\hline Netherlands & $\begin{array}{c}2002- \\
4\end{array}$ & $\begin{array}{l}\text { Contribution increase in } \\
\text { occupational pension schemes }\end{array}$ & 0.25 & 0.75 & 1 & 0 & 0 \\
\hline Netherlands & 2006 & $\begin{array}{l}\text { New rules on transparency and } \\
\text { solvency in occupational pensions }\end{array}$ & 0 & 0.75 & 1 & 0 & 0 \\
\hline UK & 1986 & $\begin{array}{l}\text { II Pillar } \\
\text { Introduction of voluntary personal } \\
\text { pensions but significant tax relief } \\
\text { Members of occupational pensions } \\
\text { were allowed to opt-out into a } \\
\text { personal pension and get a rebate }\end{array}$ & 0.75 & 0.75 & 0 & 0.75 & 0 \\
\hline
\end{tabular}




\begin{tabular}{|c|c|c|c|c|c|c|c|}
\hline Country & Year & Reform content & SPR & $\mathbf{S L}$ & $\mathbf{L F}$ & $\mathbf{S U}$ & GD \\
\hline & & paid & & & & & \\
\hline UK & 1995 & $\begin{array}{l}\text { I Pillar } \\
\text { Increase in retirement age for } \\
\text { women from } 2010 \text { with a long } \\
\text { phase in period } \\
\text { II Pillar } \\
\text { Creation of the Occupational } \\
\text { Pension Regulatory Agency } \\
\text { (OPRA) }\end{array}$ & 0.25 & 0.25 & 0 & 0.25 & 1 \\
\hline UK & 1999 & $\begin{array}{l}\text { II Pillar } \\
\text { Introduction of a duty on employers } \\
\text { to offer Group Personal Pensions }\end{array}$ & 0.75 & 0.25 & 0 & 0 & 0 \\
\hline UK & 2004 & $\begin{array}{l}\text { II Pillar } \\
\text { Replaced OPRA for The Pensions } \\
\text { Regulator. } \\
\text { Creation of the Pension Protection } \\
\text { Fund as a compensating fund }\end{array}$ & 0 & 0.25 & 0 & 0 & 0.25 \\
\hline UK & 2007 & $\begin{array}{l}\text { I Pillar } \\
\text { Reduction in years required to get a } \\
\text { full state pension } \\
\text { Change in the indexation of the I } \\
\text { Pillar State Pension and other } \\
\text { benefits to earnings } \\
\text { State pension credits for carers and } \\
\text { parents } \\
\text { Increase of retirement age for men } \\
\text { and women from } 65 \text { to } 68 \text { from } \\
2024 \\
\text { II Pillar } \\
\text { End of contracting out from state } \\
\text { second pension for personal } \\
\text { pensions from } 2012\end{array}$ & 0.25 & 0.25 & 0 & 0 & 0 \\
\hline UK & 2008 & $\begin{array}{l}\text { II Pillar } \\
\text { Introduction of automatic } \\
\text { enrolment from } 2012 \text {. Led to an } \\
\text { increase the number of workers' } \\
\text { saving into a private pension from } \\
48 \% \text { in } 2012 \text { to } \% 80 \text { in } 2017\end{array}$ & 0.75 & 0.25 & 0 & 0 & 0 \\
\hline
\end{tabular}




\begin{tabular}{|c|c|l|c|c|c|c|c|}
\hline Country & Year & \multicolumn{1}{|c|}{ Reform content } & SPR & SL & LF & SU & GD \\
\hline UK & 2011 & $\begin{array}{l}\text { I Pillar } \\
\text { Accelerates the increase in the state } \\
\text { pension age for men and women to } \\
\text { 66 from 2020 }\end{array}$ & 0.25 & 0.25 & 0.25 & 1 \\
\hline UK & 2013 & $\begin{array}{l}\text { II Pillar } \\
\text { Change in rules for public service } \\
\text { pension schemes. }\end{array}$ & 0.25 & 0 & 0.25 & 0.25 & 1 \\
\hline UK & 2014 & $\begin{array}{l}\text { I Pillar } \\
\text { Simplification of the state pension. } \\
\text { Significant because the new } \\
\text { pension is worth over 40\% more } \\
\text { than the old one. }\end{array}$ & 0.75 & 0 & 0.25 & 0.25 & 0.75 \\
\hline
\end{tabular}

